\title{
Screening of Cotton Varieties/Genotypes against Jassid, Amrasca biguttula biguttula (Ishida) under Rainfed Conditions
}

\author{
R.K. Patel* and G.G. Radadia \\ Department of Entomology, N. M. College of Agriculture, Navsari Agricultural University, \\ Navsari-396 450, Gujarat (India) \\ *Corresponding author
}

\section{A B S T R A C T}

Keywords

Cotton, Gossypium, jassid, Amrasca biguttula biguttula, screening, varieties/genotypes, Seed cotton yield

Article Info

Accepted:

10 November 2018 Available Online:

10 December 2018
Screening of sixteen cotton varieties/genotypes against jassid, Amrasca biguttula biguttula (Ishida) was carried out under rainfed conditions during kharif seasons of 2015-16 and 2016-17 at Regional Cotton Research Station, Navsari Agricultural University, Maktampur farm, Bharuch, Gujarat. The results revealed that none of the cotton variety/genotype was totally free from attack of A. biguttula biguttula and categorized as resistant based on population of jassid. Eleven varieties/genotypes viz., G.Cot.-12, GSHV-01/1338, GISV267, G.N.Cot.-22, GSHV-159, GISV-272, GBHV-177, GBHV-170, GBHV-180, GBHV164 and G.Cot.-16 were designated as moderately resistant to jassid by recording the population ranged from 2.41 to 6.37 jassids/3 leaves. The susceptible cotton varieties/genotypes comprised G.Cot.-10, LRA-5166 and G.Cot.-100 which registered population ranged from 8.11 to 11.38 jassids/3 leaves. However, genotype Cocker-310 and GSB-21 were categorized as highly susceptible to jassid with population of more than 11.73 jassids $/ 3$ leaves. The highest seed cotton yield $(2522 \mathrm{~kg} / \mathrm{ha})$ was recorded on moderately resistant genotype GISV-272. The seed cotton yield showed highly significant negative correlation with jassid population $(r=-0.646)$.

\section{Introduction}

Cotton is the most important cash crop of monsoon season in India and popularly known as "white gold". India has a unique distinction of being the only country in the world to cultivate all four cultivable Gossypium species. Gossypium hirsutum represents 99.9 per cent of the hybrid cotton in India and all the current $\mathrm{Bt}$ cotton hybrids are either $G$. hirsutum or inter-specific hybrids with $G$. barbadense. In India, cotton is grown under 40 per cent irrigated and 60 per cent rainfed conditions, Gujarat and Odisha where much of the crop is rainfed. India ranks first in cotton production (27.0 million bales of $480 \mathrm{lb}$.) as well as area (10.85 million hectares) in global scenario. However, the productivity of cotton crop in India $(542 \mathrm{~kg} / \mathrm{ha})$ is still far less than world average (781 kg/ha) in 2016-17 (Anonymous, 2018a). Gujarat leads in cotton production with 95.00 lakh bales. The provisional cotton productivity of Gujarat is $671 \mathrm{~kg} / \mathrm{ha}$ from an area of 24.05 lakh hectares in 2016-17 (Anonymous, 2018b). Cotton crop attract a variety of insect pests and mites, such 
as sucking pest complex (whitefly, jassids, thrips and mites) and bollworm pest complex (Spotted, Pink and American bollworm). Gouda et al., (2014) noted that the lower productivity of cotton was mainly due to crop grown under rainfed situation and incidence of insect pest (15-20\%). Estimated losses in cotton production due to pests were 20.9 per cent and those due to diseases as 13.5 per cent, an average (Freire et al., 1999). Chavan et al., (2010) observed that the avoidable losses due to major insect-pests (sucking pests + bollworms) were $2.94 \mathrm{q} /$ ha or 28.13 per cent.

American cotton is highly susceptible to sucking insect pests and of which jassid, $A$. biguttula biguttula also referred, as leafhopper is important sucking pest. Both nymphs and adults suck the plant sap and apparently introduce salivary toxins that impair photosynthesis in proportion to the amount of feeding. The affected leaves curl downwards, turn yellowish, then to brownish before drying and shedding. The incidence of sucking pests was more or less similar in both $B t$ and non $B t$ hybrids. Panchabhavi et al., (1990) reported that the average losses due to sucking pests (aphids, jassids and thrips) in cotton were 46.41 per cent. Singh and Lakra (1992) assessed the average reduction in yield of seed cotton due to $A$. biguttula biguttula [A. devastans] was 15.9 per cent.

The insect pest management programme against cotton jassid still relies heavily on the chemical insecticides, which lead to a destabilization of ecosystem and enhanced resistance to insect pests. To overcome these problems, varietal screening is an important component of Integrated Pest Management concept. Therefore, attempts have been made to have comprehensive information on screening of cotton varieties/genotypes against jassid, Amrasca biguttula biguttula under rainfed conditions.

\section{Materials and Methods}

Sixteen cotton varieties/genotypes were screened for their resistance/susceptibility against jassid under rainfed conditions at Regional Cotton Research Station, Navsari Agricultural University, Maktampur, Bharuch, Gujarat during kharif 2015-16 and 2016-17 (Plate-1). The seeds of different cotton varieties/genotypes were collected from Main Cotton Research Station, Navsari Agricultural University, Athwa farm, Surat and Regional Cotton Research Station, Navsari Agricultural University, Maktampur, Bharuch. The geographic location of experiments was $21.712684^{\circ} \mathrm{N}$ latitude, $73.012663^{\circ} \mathrm{E}$ longitude and $21.711245^{\circ} \mathrm{N}$ latitude, $73.012157^{\circ} \mathrm{E}$ longitude during kharif seasons of 2015-16 and 2016-17, respectively. During both kharif seasons, the crop was sown on $30^{\text {th }}$ July, 2015 and $4^{\text {th }}$ July, 2016. The experiment was laid out in Randomized Block Design replicated thrice. Each cotton variety/genotype was sown in five rows with ten dibbles in each row. The crop was sown under a spacing of 120 x $45 \mathrm{~cm}$ with $120 \mathrm{~kg} / \mathrm{ha}$ nitrogen fertilizer application and under normal agronomic practices. The field experiment was conducted with gross plot size of $7.20 \mathrm{~m} \times 5.40 \mathrm{~m}$ (cotton + okra) and $6.00 \mathrm{~m} \times 4.50 \mathrm{~m}$ (cotton crop), whereas net plot size of $3.60 \mathrm{~m}$ x $3.60 \mathrm{~m}$. The treatment details are as under.

\begin{tabular}{|c|l|c|l|}
\hline \multicolumn{4}{|c|}{ Cotton varieties/genotypes } \\
\hline $\mathrm{T}_{1}$ & GSHV-159 & $\mathrm{T}_{9}$ & G.Cot.100 \\
\hline $\mathrm{T}_{2}$ & GSHV-01/1338 & $\mathrm{T}_{10}$ & G.Cot.10 \\
\hline $\mathrm{T}_{3}$ & GISV-267 & $\mathrm{T}_{11}$ & LRA-5166 \\
\hline $\mathrm{T}_{4}$ & GISV-272 & $\mathrm{T}_{12}$ & G.Cot.16 \\
\hline $\mathrm{T}_{5}$ & GBHV-164 & $\mathrm{T}_{13}$ & $\begin{array}{l}\text { Cocker- } \\
\text { 310 }\end{array}$ \\
\hline $\mathrm{T}_{6}$ & GBHV-170 & $\mathrm{T}_{14}$ & GSB-21 \\
\hline $\mathrm{T}_{7}$ & GBHV-177 & $\mathrm{T}_{15}$ & G.Cot.12 \\
\hline $\mathrm{T}_{8}$ & GBHV-180 & $\mathrm{T}_{16}$ & G.N.Cot.22 \\
\hline
\end{tabular}




\section{Sowing of okra and cultural operations}

All the cultural operations adopted timely resulted in good crop condition till to maturity stage during both seasons. However, crop was kept free from insecticidal spray during entire crop period. Okra crop (GAO-5 variety) was grown with cotton for population buildup of jassid. One infester row of okra was sown in between each treatment of five rows of cotton variety/genotype. Two dibbles of okra were also sown in each row of cotton i.e. one dibble of okra at each side in each row having ten dibbles of cotton. Okra crop was removed after 60-75 days after sufficient population buildup of cotton jassid (Plate-2). Okra crop was also kept free from insecticidal spray.

\section{Method of recording observations}

The population of jassid was recorded at weekly interval staring from the 30 days after sowing till crop period. The observations on jassid were recorded by counting of nymphs and adults of jassid from ten randomly selected plants in each replication of different cotton varieties/genotypes. The numbers of jassids were recorded from three leaves i.e. top, middle and bottom of each selected plant.

\section{Categorization of cotton varieties/genotypes} for susceptibility to jassid based on population of jassid

The cotton varieties/genotypes were grouped into four categories of resistance to $A$. biguttula biguttula viz., resistant, moderately resistant, susceptible and highly susceptible based on number of jassids per three leaves. For the purpose, the mean value of individual genotype $\left(\overline{\mathrm{X}}_{\mathrm{i}}\right)$ was compared with mean value of all genotypes $(\overline{\mathrm{X}})$ and standard deviation (SD) following the scale adopted by Patel et al., (2002). The scale used for categorizing different genotypes was as under.

\begin{tabular}{|l|l|}
\hline $\begin{array}{l}\text { Category of } \\
\text { resistance }\end{array}$ & Scale of resistance \\
\hline Resistant $(\mathrm{R})$ & $\overline{\mathrm{X}} \mathrm{I}<(\overline{\mathrm{X}}-\mathrm{SD})$ \\
\hline $\begin{array}{l}\text { Moderately } \\
\text { Resistant }(\mathrm{MR})\end{array}$ & $\overline{\mathrm{X}} \mathrm{I}>(\overline{\mathrm{X}}-\mathrm{SD})<\overline{\mathrm{X}}$ \\
\hline $\begin{array}{l}\text { Susceptible }(\mathrm{S}) \\
\text { Highly } \\
\text { susceptible (HS) }\end{array}$ & $\overline{\mathrm{X}} \mathrm{I}>\overline{\mathrm{X}}<(\overline{\mathrm{X}}+\mathrm{SD})$ \\
\hline
\end{tabular}

\section{Seed cotton yield}

The seed cotton yield was recorded from each replication of different treatments during each picking and converted to hectare basis.

\section{Results and Discussion}

The results obtain during present studies are presented in Table 1 to 3 and depicted in Figure 1 and 2 . The season wise results are discussed hereunder.

\section{Population of jassid (2015-16)}

The data on population of jassid on different cotton varieties/genotypes during 2015-16 presented in Table 1 indicated that none of the cotton genotypes was found completely free from the attack of jassids. The cotton variety G.Cot.-12 registered less jassid population with 1.94 jassids/ 3 leaves among all cotton genotypes which was at par with GSHV$01 / 1338$ and GISV-267 by recording 2.53 and 3.19 jassids/3 leaves, respectively. The next varieties/genotypes viz., G.N.Cot.-22 (3.40 jassids/3 leaves), GSHV-159 (3.49 jassids/3 leaves) and GISV-272 (3.66 jassids/3 leaves) showed less population of jassid followed by GBHV-177 (4.33 jassids/3 leaves). Significantly the highest population of jassid was observed in GSB-21 (17.88 jassids/3 leaves). The next genotype Cocker-310 (11.82 jassids/3 leaves) showed higher jassid population followed by G.Cot.-100 (9.37 jassids/3 leaves). Two genotypes viz., G.Cot.- 
10 and LRA-5166 recorded above economic threshold level of jassid population i.e. 6.44 and 6.21 jassids $/ 3$ leaves, respectively and it was at par with each other. The rest of genotypes viz., GBHV-180, GBHV-170, GBHV-164 and G.Cot.-16 showed intermediate range of jassid population i.e. 5.07 to 5.93 jassids/ 3 leaves.

\section{Population of jassid (2016-17)}

Perusal of data presented in Table 1 on jassid population on different cotton varieties/genotypes during 2016-17 revealed that all the cotton varieties/genotypes differed significantly in population of jassid. The population of jassid on various varieties/genotypes ranged from 2.71 to 21.91 jassids/3 leaves. Genotype GSHV-01/1338 (2.71 jassids/3 leaves) recorded significantly lowest jassid population which was at par with G.Cot.-12 (2.87 jassids/3 leaves), GISV-267 (3.44 jassids/3 leaves), GSHV-159 (3.82 jassids $/ 3$ leaves) and G.N.Cot.-22 (3.85 jassids/ 3 leaves). The next varieties/genotypes viz., GISV-272 (4.20 jassids/3 leaves), GBHV-170 (4.91 jassids/3 leaves), GBHV180 (5.29 jassids/3 leaves) and GBHV-177 (5.65 jassids/3 leaves) recorded below economic threshold level of jassid population and it was at par with each other. However, significantly the highest population of jassid was observed in GSB-21 (21.91 jassids/3 leaves) and it was at par with Cocker-310 (18.38 jassids/3 leaves). The rest of varieties/genotypes viz., GBHV-164, G.Cot.16, G.Cot.-10, LRA-5166 and G.Cot.-100 registered above economic threshold level of jassid population i.e. 6.30, 6.81, 9.78, 10.83 and 13.40 jassids/3 leaves, respectively.

\section{Pooled data (2015-16 and 2016-17)}

The overall mean pooled data of year 2015-16 and 2016-17 presented in Table 1 and depicted in Figure 1 demonstrated that the population of jassid on various cotton varieties/genotypes ranged from 2.41 to 19.89 jassids/3 leaves. The lowest population of jassid was recorded in G.Cot.-12 (2.41 jassids/3 leaves) which was at par with GSHV-01/1338, GISV-267, G.N.Cot.-22, GSHV-159, GISV-272, GBHV177, GBHV-170, GBHV-180 and GBHV-164 showed jassid population of 2.62, 3.32, 3.62, $3.65,3.93,4.99,5.06,5.18$ and 5.87 jassids/ 3 leaves, respectively. However, the highest jassid population was observed in GSB-21 (19.89 jassids/3 leaves) and it was at par with Cocker-310 (15.10 jassids/3 leaves). The rest of varieties/genotypes viz., G.Cot.-16, G.Cot.10, LRA-5166 and G.Cot.-100 registered above economic threshold level of jassid population i.e. $6.37,8.11,8.52$ and 11.38 jassids $/ 3$ leaves, respectively. The ascending order of jassid population on different cotton genotypes was G.Cot.-12 < GSHV-01/1338 < GISV-267 < G.N.Cot.-22 < GSHV-159 < GISV-272 < GBHV-177 < GBHV-170 < GBHV-180 < GBHV-164 < G.Cot.-16 < G.Cot.-10 < LRA-5166 < G.Cot.-100 < Cocker-310 < GSB-21. The interaction (Year $x$ Treatment) was showed significant effects which indicated non-consistent performance of cotton genotypes over the year.

In past, Mohapatra and Nayak (2014) investigated the efficacy of twenty seven $\mathrm{Bt}$ cotton hybrids under rainfed conditions of Odisha and showed the mean population of jassid ranged from 0.72/leaf to 4.95/leaf. Yousaf et al., (2015) tested twenty five cotton genotypes and observed the minimum average population of jassid on cultivars FH-941 (1.54 and 1.47/leaf) and PB-900 (1.54 and 1.53/leaf) and found comparatively resistant however, maximum average population was found on cultivars BH-172 (10.90 and 3.04/leaf) and MNH-814 (2.61 and 3.00/leaf). The ranges of jassids population in different cotton genotypes reported by earlier scientists are more or less in line with the present investigation however they tested different cotton genotypes at different places. 
Categorization of cotton varieties/genotypes for susceptibility to jassid based on population of jassid

An attempt was made to classify different cotton varieties/genotypes with four categories of susceptibility to A. biguttula biguttula viz., Resistant (R), Moderately Resistant (MR), Susceptible (S) and Highly Susceptible (HS) based on population of jassid. Genotypes were grouped into above categories based on number of jassids $/ 3$ leaves by comparing the mean incidence of individual genotype $\left(\overline{\mathrm{X}}_{\mathrm{i}}\right)$ with mean incidence of all genotypes $(\overline{\mathrm{X}})$ and standard deviation (SD). The details of categorization are presented hereunder.

The data presented in Table 2 revealed that none of the cotton genotypes evaluated in the present study fall under categories as resistant. Eleven varieties/genotypes viz., G.Cot.-12, GSHV-01/1338, GISV-267, G.N.Cot.-22, GSHV-159, GISV-272, GBHV-177, GBHV170, GBHV-180, GBHV-164 and G.Cot.-16 were designated as moderately resistant to jassid by recording the population ranged from 2.41 to 6.37 jassids $/ 3$ leaves. The susceptible varieties/genotypes comprised G.Cot.-10, LRA-5166 and G.Cot.-100 which registered population ranged from 8.11 to 11.38 jassids $/ 3$ leaves. However, genotypes Cocker-310 and GSB-21 were categorized as highly susceptible to jassid with population of more than 11.73 jassids/ 3 leaves.

The present findings are in conformity with the findings of Patel (2014) who screened fifteen hirsutum cotton genotypes for their reaction to $A$. devastans and reported that no genotype was found resistant to jassid infestation. Ten genotypes viz., K-3, K-2, KH120, KH-121, KH-122, KH-113, JKHy-1, JK4, KH-111 and $\mathrm{KH}-119$ were categorized as tolerant (2.05 to 4.10 jassids/leaf) while five genotypes viz., KH-117, KH-134, KH-143, $\mathrm{KH}-138$ and $\mathrm{KH}-132$ as susceptible (> 4.10 jassids/leaf). Kumar et al., (2015) evaluated the resistance levels of fourteen cotton genotypes to sucking pest complex at Lam, Guntur and observed the leafhopper population early in the cropping season, gradually increased and reached to maximum between 90 to 120 days after sowing. The genotypes NDLH-1938 and L-603 had shown comparatively greater resistance against leafhoppers with the population of 6.03 and 6.30 per 3 leaves per plant and leafhopper injury index 1.25 and 1.37 respectively. The genotypes LK-861 and L-389 were highly susceptible to leafhoppers with the population of 20.10 and 20.73 per 3 leaves and leafhopper injury index 3.14 and 3.22 respectively. These findings are more or less in similar with present study however they screened different cotton genotypes at different places.

Seed cotton yield of different cotton varieties/genotypes

\section{First year (2015-16)}

The seed cotton yield obtained from different cotton varieties/genotypes and their correlation coefficient with jassid population during 2015-16 presented in Table 3 revealed that seed cotton yield was significantly influenced by different varieties/genotypes. Significantly the highest $(2053 \mathrm{~kg} / \mathrm{ha})$ seed cotton yield was recorded in genotype GISV272 which was statistically at par with GISV$267(1881 \mathrm{~kg} / \mathrm{ha})$ and GBHV-170 (1837 $\mathrm{kg} / \mathrm{ha}$ ); all these genotypes were found moderately resistant to A. biguttula biguttula. Next in line were another three moderately resistant genotypes viz., GBHV-164 (1775 $\mathrm{kg} / \mathrm{ha}), \mathrm{GBHV}-180(1658 \mathrm{~kg} / \mathrm{ha})$ and GSHV159 (1614 kg/ha). On other side the lowest seed cotton yield was recorded in GSB-21 $(413 \mathrm{~kg} / \mathrm{ha})$ which did not differ statistically from Cocker-310 (537 kg/ha); both of these genotypes were found highly susceptible to $A$. biguttula biguttula. However, the moderately 
resistant genotype G.Cot.-12 was statistically genotypes by recording seed cotton yield of at par with these two highly susceptible $589 \mathrm{~kg} / \mathrm{ha}$.

Table.1 Jassid population on different cotton varieties/genotypes under rainfed condition at Bharuch

\begin{tabular}{|c|c|c|c|c|}
\hline \multirow{2}{*}{$\begin{array}{l}\text { Sr. } \\
\text { No. }\end{array}$} & \multirow{2}{*}{$\begin{array}{c}\text { Cotton } \\
\text { varieties/genotypes }\end{array}$} & \multicolumn{3}{|c|}{ Mean number of jassids/ 3 leaves } \\
\hline & & 2015-16 & 2016-17 & Pooled \\
\hline 1 & GSHV-159 & $\begin{array}{c}1.94 \\
(3.49)^{*}\end{array}$ & $\begin{array}{c}2.00 \\
(3.82)^{*}\end{array}$ & $\begin{array}{c}1.97 \\
(3.65)\end{array}$ \\
\hline 2 & GSHV-01/1338 & $\begin{array}{c}1.67 \\
(2.53)\end{array}$ & $\begin{array}{c}1.72 \\
(2.71)\end{array}$ & $\begin{array}{c}1.70 \\
(2.62)\end{array}$ \\
\hline 3 & GISV-267 & $\begin{array}{c}1.83 \\
(3.19)\end{array}$ & $\begin{array}{c}1.91 \\
(3.44)\end{array}$ & $\begin{array}{c}1.87 \\
(3.32)\end{array}$ \\
\hline 4 & GISV-272 & $\begin{array}{c}1.98 \\
(3.66)\end{array}$ & $\begin{array}{c}2.11 \\
(4.20)\end{array}$ & $\begin{array}{c}2.05 \\
(3.93)\end{array}$ \\
\hline 5 & GBHV164 & $\begin{array}{c}2.35 \\
(5.44)\end{array}$ & $\begin{array}{c}2.52 \\
(6.30)\end{array}$ & $\begin{array}{c}2.43 \\
(5.87)\end{array}$ \\
\hline 6 & GBHV170 & $\begin{array}{c}2.33 \\
(5.21)\end{array}$ & $\begin{array}{c}2.26 \\
(4.91)\end{array}$ & $\begin{array}{c}2.30 \\
(5.06)\end{array}$ \\
\hline 7 & GBHV177 & $\begin{array}{c}2.14 \\
(4.33)\end{array}$ & $\begin{array}{c}2.43 \\
(5.65)\end{array}$ & $\begin{array}{c}2.28 \\
(4.99) \\
\end{array}$ \\
\hline 8 & GBHV180 & $\begin{array}{c}2.30 \\
(5.07)\end{array}$ & $\begin{array}{c}2.32 \\
(5.29)\end{array}$ & $\begin{array}{c}2.31 \\
(5.18)\end{array}$ \\
\hline 9 & G.Cot.-100 & $\begin{array}{c}2.95 \\
(9.37)\end{array}$ & $\begin{array}{c}3.53 \\
(13.40)\end{array}$ & $\begin{array}{c}3.24 \\
(11.38)\end{array}$ \\
\hline 10 & G.Cot.-10 & $\begin{array}{l}2.49 \\
(6.44)\end{array}$ & $\begin{array}{c}3.03 \\
(9.78)\end{array}$ & $\begin{array}{c}2.76 \\
(8.11)\end{array}$ \\
\hline 11 & LRA-5166 & $\begin{array}{c}2.48 \\
(6.21)\end{array}$ & $\begin{array}{c}3.22 \\
(10.83)\end{array}$ & $\begin{array}{c}2.85 \\
(8.52)\end{array}$ \\
\hline 12 & G. Cot. -16 & $\begin{array}{c}2.44 \\
(5.93)\end{array}$ & $\begin{array}{c}2.63 \\
(6.81)\end{array}$ & $\begin{array}{c}2.54 \\
(6.37)\end{array}$ \\
\hline 13 & Cocker-310 & $\begin{array}{c}3.39 \\
(11.82)\end{array}$ & $\begin{array}{c}4.14 \\
(18.38)\end{array}$ & $\begin{array}{c}3.77 \\
(15.10)\end{array}$ \\
\hline 14 & GSB-21 & $\begin{array}{c}4.08 \\
(17.88)\end{array}$ & $\begin{array}{c}4.49 \\
(21.91)\end{array}$ & $\begin{array}{c}4.28 \\
(19.89)\end{array}$ \\
\hline 15 & G. Cot. -12 & $\begin{array}{c}1.51 \\
(1.94)\end{array}$ & $\begin{array}{c}1.78 \\
(2.87)\end{array}$ & $\begin{array}{c}1.64 \\
(2.41)\end{array}$ \\
\hline 16 & G.N. Cot.-22 & $\begin{array}{c}1.90 \\
(3.40)\end{array}$ & $\begin{array}{c}2.02 \\
(3.85)\end{array}$ & $\begin{array}{c}1.96 \\
(3.62)\end{array}$ \\
\hline & $\mathrm{S} \operatorname{Em} \pm(\mathrm{T})$ & 0.12 & 0.13 & 0.27 \\
\hline & $\mathrm{CD}$ at $5 \%(\mathrm{~T})$ & 0.35 & 0.37 & 0.81 \\
\hline & $\mathrm{S} \mathrm{Em} \pm(\mathrm{Y} \times \mathrm{T})$ & -- & -- & 0.13 \\
\hline & $\mathrm{CD}$ at $5 \%(\mathrm{Y} \times \mathrm{T})$ & -- & -- & 0.36 \\
\hline & $\mathrm{CV}(\%)$ & 8.90 & 8.56 & 8.80 \\
\hline
\end{tabular}

*Figures in the parentheses are original mean values and those outside are $\sqrt{X+0.5}$ transformed values 
Table.2 Categorization of cotton varieties/genotypes for their susceptibility to jassids (based on mean number of jassids/3 leaves)

\begin{tabular}{|c|c|c|}
\hline $\begin{array}{c}\text { Category of } \\
\text { resistance }\end{array}$ & Scale & Cotton varieties/genotypes \\
\hline \multicolumn{2}{|c|}{ Population of jassid (numbers $/ 3$ leaves): $\bar{X}=6.88$} & $\mathrm{SD}=4.85$ \\
\hline Resistant (R) & $\overline{\mathrm{X}} \mathrm{i}<2.03$ & -- \\
\hline Moderately Resistant (MR) & $\overline{\mathrm{X}} \mathrm{i}>2.03<6.88$ & $\begin{array}{l}\text { G.Cot.-12 }(2.41)^{*} \\
\text { GSHV-01/1338 }(2.62) \\
\text { GISV-267 }(3.32) \\
\text { G.N.Cot.-22(3.62) } \\
\text { GSHV-159 }(3.65) \\
\text { GISV-272 }(3.93) \\
\text { GBHV-177 }(4.99) \\
\text { GBHV-170 }(5.06) \\
\text { GBHV-180 }(5.18) \\
\text { GBHV-164 (5.87) } \\
\text { G.Cot.-16 }(6.37)\end{array}$ \\
\hline Susceptible (S) & $\overline{\mathrm{X}} \mathrm{i}>6.88<11.73$ & $\begin{array}{l}\text { G.Cot. }-10(8.11) \\
\text { LRA-5166 }(8.52) \\
\text { G.Cot. }-100(11.38)\end{array}$ \\
\hline Highly susceptible (HS) & $\overline{\mathrm{X}} \mathrm{i}>11.73$ & $\begin{array}{l}\text { Cocker-310 (15.10) } \\
\text { GSB-21 (19.89) }\end{array}$ \\
\hline
\end{tabular}

Note: $\bar{X}=$ Mean value of all varieties/genotypes

$\overline{\mathrm{X}} \mathrm{i}=$ Mean value of individual genotype

$\mathrm{SD}=$ Standard Deviation

* Figure in the parenthesis are mean values of jassid population

Figure.1 Jassid population on different cotton varieties/genotypes (Pooled of 2015-16 and 2016-17)

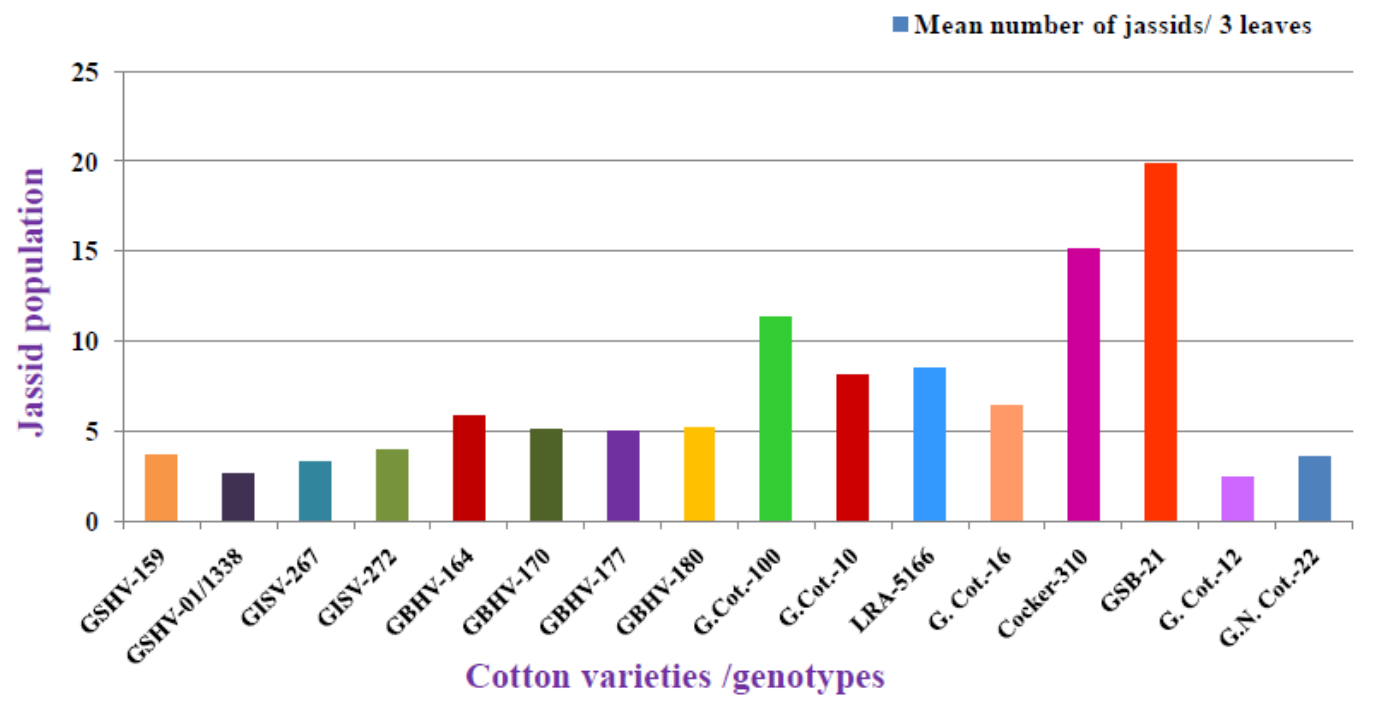


Table.3 Seed cotton yield of different cotton varieties/genotypes and its correlation with jassid population

\begin{tabular}{|c|c|c|c|c|}
\hline \multirow{2}{*}{$\begin{array}{l}\text { Sr. } \\
\text { No. }\end{array}$} & \multirow{2}{*}{$\begin{array}{c}\text { Cotton } \\
\text { varieties/ genotypes }\end{array}$} & \multicolumn{3}{|c|}{ Seed cotton yield (kg/ha) } \\
\hline & & 2015-16 & 2016-17 & Pooled \\
\hline 1 & GSHV-159 & 1614 & 2815 & 2215 \\
\hline 2 & GSHV-01/1338 & 1442 & 2738 & 2090 \\
\hline 3 & GISV-267 & 1881 & 2872 & 2377 \\
\hline 4 & GISV-272 & 2053 & 2990 & 2522 \\
\hline 5 & GBHV164 & 1775 & 2457 & 2116 \\
\hline 6 & GBHV170 & 1837 & 2883 & 2360 \\
\hline 7 & GBHV177 & 1364 & 1761 & 1563 \\
\hline 8 & GBHV180 & 1658 & 2645 & 2152 \\
\hline 9 & G.Cot. -100 & 844 & 1553 & 1199 \\
\hline 10 & G.Cot.-10 & 1023 & 1806 & 1415 \\
\hline 11 & LRA-5166 & 956 & 1232 & 1094 \\
\hline 12 & G. Cot.-16 & 1418 & 1822 & 1620 \\
\hline 13 & Cocker-310 & 537 & 1139 & 838 \\
\hline 14 & GSB-21 & 413 & 921 & 667 \\
\hline 15 & G. Cot.-12 & 589 & 663 & 626 \\
\hline 16 & G.N. Cot.-22 & 1311 & 2254 & 1783 \\
\hline & $\mathrm{S} E m \pm(T)$ & 94.26 & 118.20 & 172.61 \\
\hline & $\mathrm{CD}$ at $5 \%(\mathrm{~T})$ & 272.20 & 341.33 & 520.20 \\
\hline & $\mathrm{S} E m \pm(\mathrm{Y} \times \mathrm{T})$ & -- & -- & 106.90 \\
\hline & $\mathrm{CD}$ at $5 \%(\mathrm{Y} \times \mathrm{T})$ & -- & -- & 302.36 \\
\hline & CV (\%) & 12.61 & 10.06 & 11.12 \\
\hline Cor & elation coefficient (' $r$ ') & $-0.630 * *$ & $-0.638 * *$ & $-0.646 * *$ \\
\hline
\end{tabular}

* Significant at $5 \%$ level of significance * * Significant at $1 \%$ level of significance 
Figure.2 Seed cotton yield of different cotton varieties/genotypes and its correlation with jassid population (Pooled of 2015-16 and 2016-17)

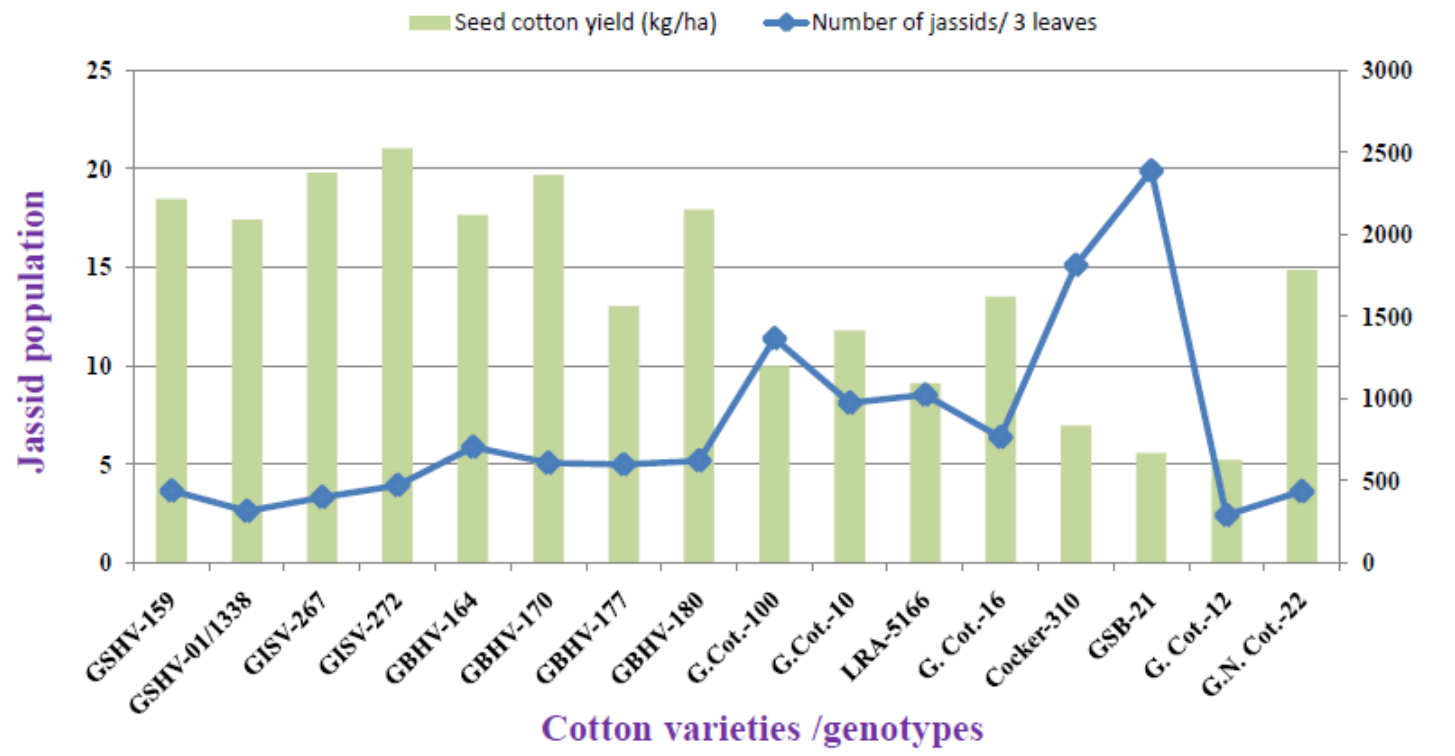

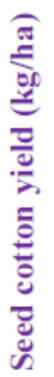

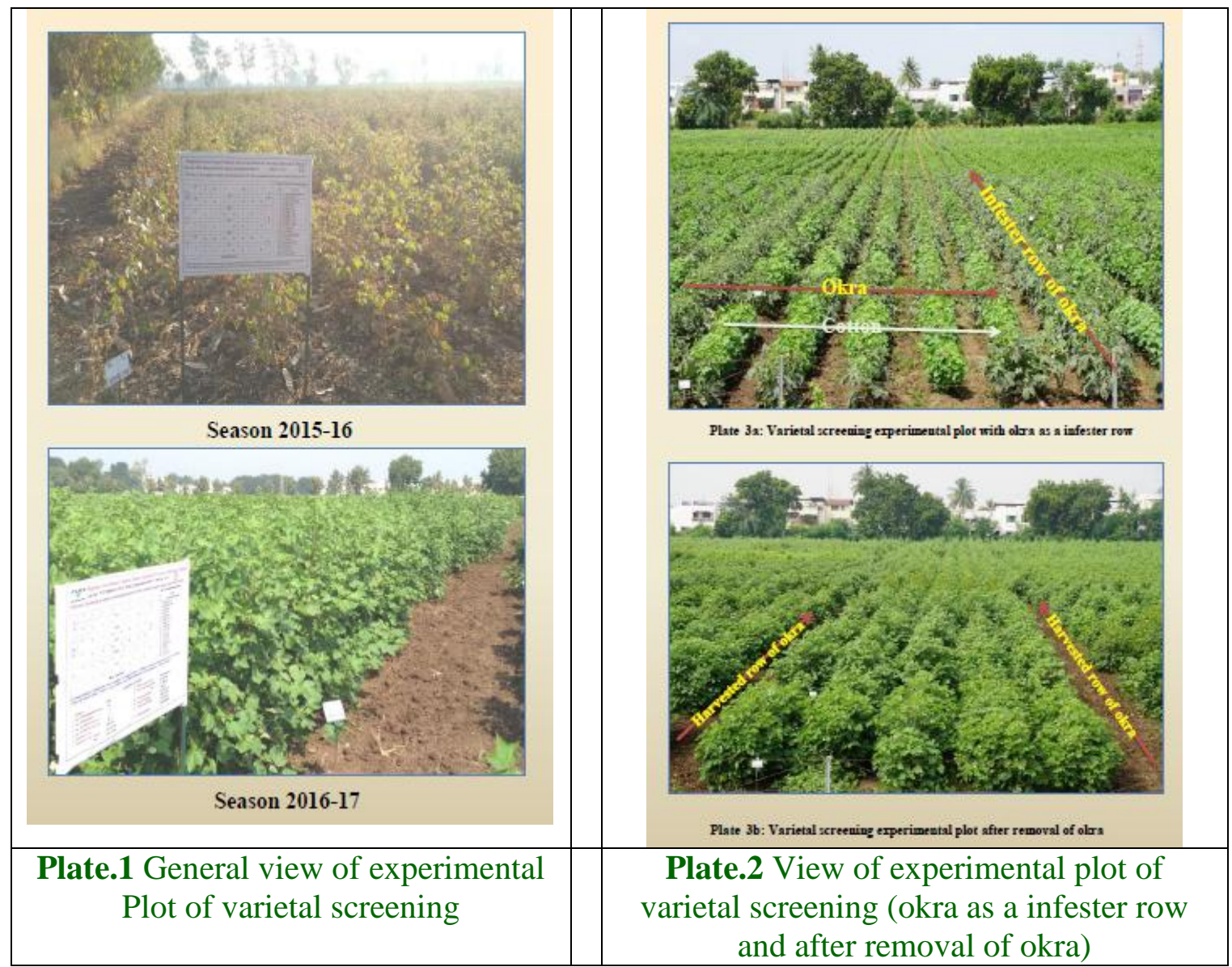


The rest of cotton genotypes recorded seed cotton yield ranged from 844 to $1442 \mathrm{~kg} / \mathrm{ha}$. The seed cotton yield showed highly significant negative correlation with jassid population $(r=-0.630)$ implying that increase in the infestation corresponds with decrease of the seed cotton yield and vice-versa.

\section{Second year (2016-17)}

During 2016-17, significantly the highest (2990 kg/ha) seed cotton yield was recorded in genotype GISV-272 which was statistically at par with GBHV-170 (2883 kg/ha), GISV267 (2872 kg/ha), GSHV-159 (2815 kg/ha) and GSHV-01/1338 (2738 kg/ha); all these genotypes were found moderately resistant to A. biguttula biguttula. Whereas, significantly the lowest $(663 \mathrm{~kg} / \mathrm{ha}$ ) seed cotton yield was obtained in moderately resistant genotype G.Cot.-12 and it was statistically at par with highly susceptible genotype GSB-21 (921 $\mathrm{kg} / \mathrm{ha}$ ). The GSB-21 was statistically at par with another highly susceptible genotype Cocker-310 (1139 kg/ha) and susceptible genotype LRA-5166 (1232 kg/ha). The rest of cotton genotypes registered intermediate range of seed cotton yield (1553 to 2645 $\mathrm{kg} / \mathrm{ha}$ ). The correlation study revealed that seed cotton yield showed highly significant negative correlation with jassid population $(r=$ -0.638) implying that increase in the infestation corresponds with decrease of the seed cotton yield and vice-versa.

\section{Pooled data (2015-16 and 2016-17)}

The pooled data of year 2015-16 and 2016-17 presented in Table 3 and depicted in Figure 2 indicated that GISV-272 performed best by attaining the highest seed cotton yield (2522 $\mathrm{kg} / \mathrm{ha}$ ) which was statistically at par with GISV-267 (2377 kg/ha), GBHV-170 (2360 $\mathrm{kg} / \mathrm{ha}$ ), GSHV-159 (2215 kg/ha), GBHV-180 (2152 kg/ha), GBHV-164 (2116 kg/ha) and GSHV-01/1338 (2090 kg/ha); all these varieties/genotypes were found moderately resistant to A. biguttula biguttula. However, significantly the lowest $(626 \mathrm{~kg} / \mathrm{ha})$ seed cotton yield was obtained in moderately resistant genotype G.Cot.-12 and it was statistically at par with two highly susceptible genotypes viz., GSB-21 (667 kg/ha) and Cocker-310 (838 kg/ha) as well as the susceptible genotype LRA-5166 (1094 kg/ha). The interaction (Year $x$ Treatment) had significant effect which indicated nonconsistent performance of seed cotton yield over the year. When the seed cotton yield was statistically correlated, it exhibited highly significant negative correlation with jassid population $(\mathrm{r}=-0.646)$ implying that increase in jassid infestation corresponds with decrease of the seed cotton yield and vice-versa.

In past, Pathan et al., (2007) reported that CRIS-467 was highly susceptible to bollworms and jassid resulting in the lowest seed cotton yield of $530.2 \mathrm{~kg} / \mathrm{ha}$, whereas CRIS-468 was highly resistant having a maximum yield of $1021.0 \mathrm{~kg} / \mathrm{ha}$ among evaluated of six cotton strains. Khan et al., (2011) reflected that IR-443 proved to be the most successful genotype rendering lowest infestation of jassids ( 0.30 and $0.42 /$ leaf), thrips and whiteflies with highest yield (1628 and $1599 \mathrm{~kg} / \mathrm{acre}$ ) in both years as compared to other Bt cotton genotypes followed by IRFH-901. Further, Sarwar et al., (2013) observed that the N-Karishma carried minimum jassid load (1.70 per leaf) considering the best for pest resistance with highest cotton production $\left(8.53 \mathrm{~kg}\right.$ per $\left.30 \mathrm{~m}^{2}\right)$ in comparison to other ten released $G$. hirsutum cotton varieties. Moreover, Patel (2014) evaluated that the genotype K-3 recorded minimum jassid population and gave maximum seed cotton yield, followed by $\mathrm{KH}-$ 121 and K-2 among fifteen hirsutum cotton genotypes screened. The results of present investigation are more or less in conformation with earlier investigations. The variation in 
the yield of seed cotton as reported by other scientists it might be due to different varieties/genotypes as well as different climatic conditions.

In conclusion, screening studies revealed that none of the cotton variety/genotype was totally free from attack of $A$. biguttula biguttula and categorized as resistant based on population of jassid. Eleven varieties/genotypes viz., G.Cot.-12, GSHV01/1338, GISV-267, G.N.Cot.-22, GSHV159, GISV-272, GBHV-177, GBHV-170, GBHV-180, GBHV-164 and G.Cot.-16 were moderately resistant, whereas G.Cot.-10, LRA-5166 and G.Cot.-100 were susceptible to jassid. However, Cocker-310 and GSB-21 were categorized as highly susceptible to jassid. The seed cotton yield showed highly significant negative correlation with jassid population.

\section{Acknowledgement}

Authors are sincerely thankful to the Director of Research and Dean, Post Graduate Studies and the Principal and Dean, N. M. College of Agriculture, Navsari Agricultural University for providing necessary facilities to conducting the research work.

\section{References}

Anonymous (2018a). World Agricultural Production, United States Department of Agriculture (USDA), October 2018, pp.30. [Fide: www.apps.fas.usda.gov

Anonymous (2018b). All India Coordinated Research Project on Cotton (AICRP), ICAR-Central Institute for Cotton Research, Coimbatore, Annual report: 2017-18, pp.A-3-4.

Chavan, S. J., Bhosle, B. B. and Bhute, N. K. (2010). Estimation of losses due to major insect-pests in desi cotton (Gossypium arboreum L.) in
Maharashtra. J. Cotton Res. Dev., 24(1): 95-96.

Freire, E. C., Farias, F. J. C. and Aguiar, P. H. (1999). Estimated losses in cotton production due to pests and diseases in the central-west region- harvest 1998/99. [In: Anais II Congresso Brasileiro de Algodao, Brasil, pp.1-3]. [Fide: RAE, 2000 Vol. 88 No. 6: 5175]

Gouda, B. P., Ashok, M. B., Navi, S. S. and Doreswamy, C. (2014). Impact of integrated pest management technologies in rainfed cotton and created job opportunities for rural youth and farm women in the Mysore district of Karnataka. Int. J. Tropical Agric. 32(1-2): 105-108.

Khan, M. H., Ahmad, N. and Tofique, M. (2011). Screening of different Bt cotton (Gossypium hirsutum L.) genotypes against sucking and bollworm complexes. The Nucleus, 48(4): 343347.

Kumar, B. D., Sridevi, D., Babu, T. R. and Radhakrishna, K. V. (2015). Determination of trichome density in different dual toxin transgenic Bt cotton (Gossypium spp.) hybrids (BG-II) and non-Bt. J. Res. PJTSAU, 43(3): 28-29.

Mohapatra, L. N. and Nayak, S. K. (2014). Performance of $B t$ cotton hybrids against sucking pests under rainfed condition in Odisha. J. Pl. Protec. Env., 11(2): 115-117.

Panchabhavi, K. S., Kulkarni, K. A., Veeresh, G. K., Hiremath, P. C. and Hegde, R. K. (1990). Comparative efficiency of techniques for assessing loss due to insect pests in upland cotton (Gossypium hirsutum). Indian J. Agri. Sci., 60(4): 252-254. [Fide: RAE, 1991 Vol. 79 No. 8: 7950]

Patel, I. S., Prajapati, B. G., Patel, G. M. and Pathak, A. R. (2002). Response of castor genotypes to castor semilooper, Achaea janata Fab. J. Oilseeds Res., 
19(1): 153.

Patel, Y. (2014). Reaction of cotton genotypes to Amrasca devastans (Distant) vis-a-vis crop age. Ann. Pl. Protec. Sci., 22(1): 49-51.

Pathan, A. K., Chohan, S., Leghari, M. A., Chandio, A. S. and Sajjad, A. (2007). Comparative resistance of different cotton genotypes against insect pest complex of cotton. Sarhad J. Agric., 23(1): 141-143.

Sarwar, M., Hamed, M., Yousaf, M. and Hussain, M. (2013). Identification of resistance to insect pests infestations in cotton (Gossypium hirsutum L.) varieties evaluated in the field experiment. Intl. J. Scientific Res. Env.
Sci., 1(11): 317-323.

Singh, J. P. and Lakra, R. K. (1992). Effect of incidence of leafhopper and bollworms on shedding of fruiting bodies and loss in yield of seed cotton. [In: Proceedings of the $3^{\text {rd }}$ International conference of Plant Protection in the Tropics, 6: 142148]. [Fide: RAE, 1993 Vol. 81 No. 5: 5079]

Yousaf, M. J., Nadeem, I., Niaz, T., Ahmed, R., Akhtar, M. F. and Raza A. (2015). Response of some new cotton genotypes against insect pests complex and cotton leaf curl virus. J. Ent. Zool. Studies, 3(2): 211-214.

\section{How to cite this article:}

Patel, R.K. and Radadia, G.G. 2018. Screening of Cotton Varieties/Genotypes against Jassid, Amrasca biguttula biguttula (Ishida) under Rainfed Conditions. Int.J.Curr.Microbiol.App.Sci. 7(12): 1099-1110. doi: https://doi.org/10.20546/ijcmas.2018.712.136 